Jurnal Akuntansi \& Perpajakan, Volume 1, No. 2, Januari 2020

\title{
ANALISIS PENGARUH PROFITABILITAS DAN INVESTASI ASET TETAP TERHADAP NILAI PERUSAHAAN MANUFAKTUR (SUB-SEKTOR KONSUMSI) YANG TERDAFTAR DI BURSA EFEK INDONESIA PADA TAHUN 2015-2017
}

\author{
Axel Nastalim, Yudith Dyah Hapsari \\ Fakultas Ekonomi dan Bisnis \\ Universitas Katolik Indonesia Atma Jaya
}

\begin{abstract}
ABSTRAK
Tujuan dari penelitian ini adalah untuk mengetahui pengaruh profitabilitas dan investasi aset tetap terhadap nilai perusahaan. Objek penelitian ini adalah perusahaan manufaktur terdaftar di Bursa Efek Indonesia sub-sektor konsumsi pada tahun 2015-2017. Dari 39 perusahaan yang terdaftar, hanya 18 yang memenuhi syarat; perusahaan manufaktur yang terdaftar di Bursa Efek Indonesia pada tahun 2015-2017 dan laporan keuangannya telah diaudit oleh auditor independen, perusahaan telah menerbitkan laporan tahunannya, dimana laporan tahunan tersebut dipublikasikan melalui situs resmi Bursa Efek Indonesia atau situs resmi masing-masing perusahaan, perusahaan telah melakukan penawaran saham perdana (Initial Public Offering / IPO) sebelum tahun 2015, perusahaan menyajikan laporan keuangan dan laporan tahunannya dalam mata uang rupiah $(\mathrm{Rp})$, laporan keuangan dan laporan tahunan perusahaan manufaktur menyediakan data terkait variabel-variabel yang digunakan dalam penelitian. Hasil analisis diketahui bahwa variabel profitabilitas berpengaruh positif dan signifikan terhadap nilai perusahaan, sedangkan variabel investasi aset tetap berpengaruh positif namun tidak signifikan terhadap nilai perusahaan.
\end{abstract}

Kata-kata Kunci: Profitabilitas, Investasi Aset Tetap, ROA, CAPBVA, Nilai Perusahaan.

Korespondensi: Yudith Dyah Hapsari, S.E., M.M. Universitas katolik Indonesia Atma Jaya. Fakultas Ekonomi dan Bisnis Universitas Katolik Indonesia Atma Jaya, Jl. Jendral Sudirman No. 51, Jakarta, 12930. Email: yudithd.hapsari@atmajaya.ac.id 
Jurnal Akuntansi \& Perpajakan, Volume 1, No. 2, Januari 2020

\section{PENDAHULUAN}

Perkembangan teknologi yang sangat pesat dan maju menunjang investasi di Pasar modal Indonesia. Peran pasar modal Indonesia sebagai salah satu media penyaluran dana antara investor ke perusahaan semakin penting.

Menurut Bodie, Kane, dan Markus (2014:47), investasi adalah komitmen saat ini atas uang atau sumber daya lain dengan harapan untuk memperoleh keuntungan di masa depan. Sebagai contoh, seorang investor mungkin membeli beberapa lembar saham mengantisipasi pendapatan yang akan datang dan sebagai pembenaran waktu yang terikat terikat maupun resiko investiasi.

Ketika melakukan investasi di pasar modal, maka investor akan melihat keuntungan / return dari investasinya melalui dua hal yaitu capital gain yang merupakan selisih yang terjadi antara harga beli dan harga jual, dan dividen yang merupakan pembagian sebagian keuntungan perusahaan (Sembel dan Sugiharto, 2009:129).

Dari sudut pandang perusahaan, tujuan manajemen keuangan adalah memaksimalkan nilai dari saham yang ada (Ross, Westerfield, Jordan, Lim, Tan, 2012:9). Dan Untuk mencapai tujuan ini, manajer keuangan harus mampu melaksanakan fungsi- fungsinya dengan baik, yaitu: pendanaan (financing decision), investasi (investment decision), dan kebijakan dividen (dividend decision).
Berhubungan dengan teori signal (signaling theory), Brigham dan Houston (2010:7) menyatakan bahwa signaling theory merupakan suatu tindakan yang diambil perusahaan untuk memberikan petunjuk bagi investor tentang bagaimana manajemen memandang prospek perusahaan. Menurut penelitian Soliha and Taswan (2002), profit yang tinggi akan akan memberi indikasi prospek,sehingga dapat memicu investor untuk ikut meningkatkan saham, hal ini menyebabkan kenaikan permintaan saham perusahaan, dan menyebabkan peningkatan nilai perusahaan. Profitabilitas memperlihatkan sejauh mana perusahaan mengelola modal sendiri secara efektif, mengukur tingkat keuntungan dari investasi yang telah dilakukan oleh pemilik modal sendiri atau pemegang saham (Sawir, 2005). Semakin baik pertumbuhan profitabilitas perusahaan berarti prospek perusahaan di masa depan dinilai semakin baik, artinya nilai perusahaan juga akan dinilai semakin baik di mata investor. Apabila kemampuan perusahaan untuk menghasilkan laba meningkat, maka harga saham juga akan meningkat (Husnan, 2001:317).

Nilai perusahaan yang dibentuk melalui nilai pasar saham sangat dipengaruhi oleh peluang-peluang serta pilihan-pilihan investasi di masa depan yang dikenal dengan Investment Opportunity Set. Menurut Ratnawati (2007), Investment Opportunity Set (IOS) merupakan hasil dari pilihan-pilihan untuk membuat 
Jurnal Akuntansi \& Perpajakan, Volume 1, No. 2, Januari 2020

investasi di masa mendatang Wahyudi dan Pawestri (2006). Nilai perusahaan yang dibentuk melalui nilai pasar saham sangat dipengaruhi oleh peluang-peluang serta pilihan-pilihan invesasi di masa yang akan datang. Dan Investment Opportunity Set (IOS) merupakan hasil dari pilihan-pilihan untuk membuat investasi di masa mendatang Ratnawati (2007).

Dalam penelitian yang dilakukan oleh Hasnawati (2005), Wijaya \& Wibawa (2010) dan Fuji (2012), menunjukkan adanya pengaruh signifikan antara IOS yang didekati dengan pendekatan CAPBVA terhadap nilai perusahaan. Berbeda dengan hasil penelitian di atas, Soejono (2010) menunjukkan bahwa IOS (CAPBVA) tidak berpengaruh signifikan terhadap nilai perusahaan.

Karena adanya research gap dari penelitian-penelitian sebelumnya, maka penulis tertarik untuk meneliti faktor yang mempengaruhi nilai perusahaan, khususnya perusahaan yang bergerak dalam industri manufaktur sektor consumer goods industry. Faktor-faktor yang akan diteliti meliputi profitabilitas (Return-on-Assets) dan investasi aset tetap (CAPBVA).

\section{LITERATURE REVIEW}

\section{Signaling Theory}

Brigham dan Houston (2010:7) menyatakan bahwa signaling theory merupakan suatu tindakan yang diambil perusahaan untuk memberikan petunjuk bagi investor tentang bagaimana manajemen memandang prospek perusahaan. Menurut Fenandar (2012:4), sinyal dapat berupa informasi mengenai apa yang sudah dilakukan oleh manajemen untuk merealisasikan keinginan pemilik. Sinyal dapat berupa informasi yang menyatakan bahwa perusahaan tersebut lebih baik dari pada perusahaan lain.

Menurut Wahyuni, Ernawati, Murhadi (2013) menyatakan bahwa pihak internal perusahaan umumnya memiliki informasi yang lebih baik dan lebih cepat berkaitan dengan kondisi dan prospek perusahaan yang sebenarnya dibandingkan dengan investor luar. Kondisi seperti inilah yang dinamakan asymmetric information. Munculnya asymmetric information tersebut menyulitkan pihak investor dalam menilai secara obyektif berkaitan dengan kualitas perusahaan.

\section{Profitabilitas}

Menurut Kasmir (2008), rasio profitabilitas merupakan rasio yang digunakan untuk melihat kemampuan perusahaan dalam mencari keuntungan. Profitabilitas penting dalam usaha mempertahankan kelangsungan hidup perusahaan dalam jangka panjang, karena profitabilitas menunjukkan apakah perusahaan tersebut mempunyai prospek yang baik di masa yang akan datang.

Berdasarkan pengertian dari para ahli di atas, dapat penulis simpulkan bahwa profitabilitas didasari dengan teori signaling. Dari laporan keuangan perusahaan dapat dilihat profitabilitasnya yang akan memberi sinyal pada 
Jurnal Akuntansi \& Perpajakan, Volume 1, No. 2, Januari 2020

calon investor apakah perusahaan tersebut mempunyai prospek baik untuk menjadi tempat investasi atau tidak.

Return on Asset (ROA) adalah salah satu proksi yang dapat menjelaskan hubungan dari profitabilitas dengan nilai perusahaan. Menurut Brigham dan Houston (2009:96), pengembalian atas total aktiva (ROA) dihitung dengan cara membandingkan laba bersih yang tersedia untuk pemegang saham biasa dengan total aktiva.

$$
R O A=\frac{\text { Net Income }}{\text { Total Assets }}
$$

\section{Aset Tetap}

Menurut Baridwan (2008: 271), pengertian aset tetap adalah: Aset-aset yang berwujud yang sifatnya relatif permanen digunakan dalam kegiatan perusahaan yang normal. Istilah permanen menunjukkan sifat dimana aset yang bersangkutan dapat digunakan dalam waktu yang relatif lama.

Sedangkan menurut Warren (2015:493), aset tetap (fixed asset) adalah "aset yang bersifat jangka panjang atau secara relatif memiliki sifat permanen seperti peralatan, mesin, gedung, dan tanah" Berdasarkan beberapa pengertian di atas maka penulis dapat menyimpulkan bahwa aset tetap merupakan salah satu jenis kekayaan yang dimiliki oleh perusahaan yang dibeli bukan untuk dijual tetapi untuk menjadi sarana untuk menghasilkan uang bagi perusahaan, yang digunakan untuk memperlancar kegiatan operasional perusahaan dan dapat digunakan lebih dari satu periode akuntansi.

\section{Capital Expenditure}

Capital expenditure (belanja modal) sering disebut juga sebagai capital expense atau capital spending. Beberapa definisi mengenai capital expenditure menurut para ahli, yaitu:

- Capital expenditure merupakan pengeluaran dana yang dilakukan manajemen untuk membiayai tambahan aset yang diperukan guna mendukung pertumbuhan perusahaan." (Sartono, 2001:56)

○ "Capital expenditure merupakan investasi yang dikeluarkan dengan harapan akan menghasilkan aliran kas masuk di masa depan. Oleh karenanya dibutuhkan persiapan yang matang dalam merencanakan capital expenditure." - Saphiro $(2014: 538)$

\section{Investment Opportunity Set}

Set kesempatan investasi atau investment opportunity set (IOS) pertama kali diperkenalkan oleh Myers (1977) yang menguraikan perusahaan sebagai kesempatan investasi dalam bentuk kombinasi antara aktiva yang dimiliki (asset in place) dan pilihan Investasi pada masa mendatang dengan net present value (NPV) positif yang akan mempengaruhi nilai perusahaan.

Menurut Gaver \& Gaver (1993), investment opportunity set bersifat tidak dapat diobservasi. Karena sifat IOS yang merupakan variabel tersembunyi ini mengindikasikan IOS tidak dapat diobservasi. Untuk dapat mengetahui ukuran suatu IOS, maka dibutuhkan proksi IOS yang dapat dihubungkan dengan variabel lain dalam 
Jurnal Akuntansi \& Perpajakan, Volume 1, No. 2, Januari 2020

perusahaan. Proksi IOS bervariasi bentuknya dan diklasifikasi menjadi 3 jenis utama, Gaver \& Gaver 1993, Jones \& Sharma 2001, dan Kallapur \& Trombley 2001, (dalam Gagaring 2003) yaitu: Proksi IOS berdasarkan harga (price-based proxies); Proksi IOS berdasarkan investasi (investment-based proxies); Proksi IOS berdasarkan varian (variance measures).

Dalam penelitian ini, penulis menggunakan proksi berdasarkan investasi dengan menggunakan rasio Capital Expenditure to Book Value Assets. Rasio ini menunjukkan adanya aliran tambahan modal saham perusahaan untuk tambahan aktiva produktif sehingga berpotensi terhadap pertumbuhan perusahaan (Julianto, 2003). Hal ini ditunjukkan dengan selisih nilai aktiva tetap perusahaan dibagi dengan total aset perusahaan.

CAPBVA $=\frac{\text { Nilai Buku AT } T_{t}-\text { Nilai BukuAT }}{t-i}$

\section{Nilai Perusahaan}

Nilai perusahaan yang harus diperhatikan manajer keuangan adalah nilai jangka Panjang dari saham perusahaan (Brigham dan Houston, 2009:9)

\section{Pecking Order Theory}

Teori struktur modal pecking-order yang dikemukakan oleh Myers dan Maljuf (1984). digunakan untuk menentukan keputusan finansial bersifat relevan atau tidak relevan. Teori peckingorder menyatakan bahwa perusahaan baru dapat memanfaatkan sumber dana dari sumber luar (utang) jika sumber internal (laba ditahan) sudah habis, karena perusahaan merasa bahwa sumber pendanaan internal akan lebih aman dibanding eksternal. Sumber pendanaan eksternal yang akan terlebih dahulu dipilih adalah utang, bukan ekuitas, karena ekuitas memiliki masalah adverse selection yang lebih tinggi.

Dalam penelitian ini, penulis menggunakan Tobin's Q sebagai proksi untuk mengukur variable Y ( Nilai Perusahaan). Menurut Menurut Ross, Westerfield \& Jordan (2010:64), rumus ini dinilai lebih baik daripada M/BV Ratio untuk menghitung nilai suatu perusahaan karena rumus ini memperhatikan nilai aset perusahaan saat ini dan biaya untuk menggantikannya. Dengan rumus:

$$
\text { Tobin's } \mathrm{Q}=\frac{\text { Market Value of Firm's Assets }}{\text { Replacement Cost of Firm'sAssets }}
$$

\section{Hubungan antar variable}

Penelitian sebelumnya yang dilakukan oleh Astriani (2014) mengenai pengaruh profitabilitas terhadap nilai perusahaan menggunakan proksi ROA sebagai alat untuk mengukurnya memberikan hasil bahwa variabel profitabilitas berpengaruh positif terhadap nilai perusahaan.

Hal ini disebabkan karena perusahaan yang mengalami peningkatan laba mencerminkan bahwa perusahaan mempunyai kinerja yang baik, sehingga menimbulkan sentimen positif dari investor dan dapat membuat harga saham perusahaan mengalami peningkatan, meningkatnya harga saham di pasar berarti meningkat pula nilai perusahaan di mata investor.

Berbeda dengan kesimpulan yang dapat diambil dari penelitian di atas, penelitian yang dilakukan oleh Noviyanto (2008) menunjukkan bahwa profitabilitas tidak berpengaruh terhadap 
Jurnal Akuntansi \& Perpajakan, Volume 1, No. 2, Januari 2020

nilai perusahaan. Alasan dari tidak berpengaruhnya profitabilitas terhadap nilai perusahaan diartikan oleh Noviyanto disebabkan karena laba yang didapatkan perusahaan tidak stabil dari tahun ketahun dan cenderung berfluktuatif sehingga investor tidak yakin dengan hasil yang akan didapat perusahaan dimasa mendatang.

Selain profitabilitas, variabel $\mathrm{X}$ lainnya dalam penelitian ini adalah investasi aset tetap. Variabel Investasi aset tetap diproksikan dengan CAPBVA. Beberapa penelitian sebelumnya memiliki kesimpulan bahwa variabel investasi aset tetap terhadap nilai perusahaan memiliki pengaruh positif dan signifikan menurut Jiang, Chen, Huang (2006), sedangkan menurut Murhadi W. R. (2008), investasi aset tetap memiliki pengaruh positif namun tidak signifikan terhadap nilai perusahaan. Hal ini menunjukkan bahwa perusahaan mampu mengelola tambahan modal saham perusahaan untuk meningkatkan aktiva produktif sehingga berpotensi dalam meningkatkan pertumbuhan perusahaan. Di sisi lain, penelitian yang dilakukan oleh Feixue Xie (2000), Susanny (2011) memiliki kesimpulan bahwa IFA tidak berpengaruh terhadap nilai perusahaan.

Berikut adalah hipotesis pada penelitian ini:

H1: Profitabilitas memiliki pengaruh positif terhadap nilai perusahaan.

$\mathrm{H} 2$ : Investasi aset tetap memiliki pengaruh positif terhadap nilai perusahaan

\section{METHODS}

\section{Definisi Operasional Variabel}

Variabel nilai perusahaan

Nilai perusahaan diukur dengan menggunakan rumus Tobin's Q yang merupakan metode pengukuran nilai perusahaan yang dipandang lebih bisa diandalkan karena menunjukkan nilai perusahaan dalam rentang waktu jangka panjang (Siddiqui, 2015). Rumus Tobin's Q yang digunakan adalah rumus yang telah dikembangkan oleh Chung \& Pruitt (1994), yaitu:

Tobin's $\mathrm{Q}=\frac{M V E+P S+D e b t}{T A}$

$\underline{\text { Keterangan : }}$

Firm Value $=$ Approximate $Q$

$\mathrm{MVE}=$ Harga pasar saham biasa per lembar $\mathrm{X}$ jumlah saham biasa beredar

PS = Nilai likuidasi saham preferen per lembar $\mathrm{X}$ jumlah saham preferen beredar

Debt $=$ Total kewajiban jangka pendek - aset lancar + total utang jangka panjang

TA = Nilai buku total aset perusahaan

\section{Profitabilitas}

Dalam penelitian ini, profitabilitas diukur dengan menggunakan return of asset (ROA) sebagai proksinya, karena ROA dianggap sebagai proksi yang paling bisa mewakili penghitungan profitabilitas dengan membandingkan laba bersih dengan total aset yang ada, sehingga dari perbandingan yang ada dapat dilihat seberapa besar pengaruh aset terhadap laba bersih 
Jurnal Akuntansi \& Perpajakan, Volume 1, No. 2, Januari 2020

perusahaan. Semakin besar (lebih dari 1) maka akan semakin baik bagi perusahaan

ROA $=\frac{\text { Laba Bersih }}{\text { Total Aset }}$

\section{Investasi aset tetap (IFA)}

Dalam penelitian ini, proksi investasi (CAPBVA) sesyai dengan penelitian Julianto (2003) dipilih sebagai proxy Investment Opportunity Set.

CAPBVA $=\frac{\text { Nilai Buku AT }_{t-\text { Nilai Buku } A T_{t-i}}}{\text { Total Aktiva }^{\text {Cot }}}$

\section{Metode Pengumpulan Data}

Obyek penelitian ini adalah perusahan manufaktur sub sector konsumsi. Data yang dikumpulkan adalah data dari tahun $2015-2017$ berupa data sekunder.

\section{Metode Analisis Data}

Metode analisis data yang digunakan dalam penelitian ini adalah analisis statistika deskriptif dan regresi data panel. Data panenel digunakan karena data berupa cross section dan time series Analisis statistika deskriptif akan dilakukan dengan menggunakan perangkat lunak Microsoft Excel sedangkan regresi data panel akan dilakukan dengan perangkat lunak Eviews.

\section{RESULTS AND DISCUSSION}

Dari 39 perusahaan yang tercatat di sub-sektor konsumsi, hanya 18 perusahaan yang memenuhi kriteria data yang dibutuhkan. Karena adanya batasan atau kriteria: perusahaan manufaktur yang terdaftar di Bursa Efek Indonesia pada tahun 2015-2017 dan laporan keuangannya telah diaudit oleh auditor independen; perusahaan telah menerbitkan laporan tahunan dan telah dipublikasikan melalui situs resmi Bursa Efek Indonesia atau situs resmi masing-masing perusahaan; perusahaan telah melakukan penawaran saham perdana (Initial Public Offering/IPO) sebelum tahun 2015, perusahaan menyajikan laporan keuangan dan laporan tahunannya dalam mata uang rupiah (Rp); laporan keuangan dan laporan tahunan perusahaan manufaktur menyediakan data terkait variabel-variabel yang digunakan dalam penelitian.

Penulis memilih perusahaan di dalam sektor manufaktur sub-sektor konsumsi sebagai objek penelitian karena sektor manufaktur memiliki jumlah yang cukup banyak, sub-sektor konsumsi dipilih oleh penulis karena rata-rata dari perusahaan dalam sub-sektor ini memiliki total aset yang cukup besar untuk bisa mewakili profitabilitas yang penulis ukur lewat penghitungan ROA dan juga investasi aset tetap yang penulis ukur lewat CAPBVA.

Tabel Saham Perusahaan Obyek Penelitian

\begin{tabular}{|c|c|c|}
\hline No & Kode Saham & Nama Perusahaan \\
\hline & & AKASHA WIRA \\
1 & ADES & INTERNATIONAL \\
& & TBK \\
\hline & & TIGA PILAR \\
& AISA & TEJAHTERA FOOD \\
& & TRI BANYAN TIRTA \\
3 & ALTO & TBK \\
& & \\
\hline
\end{tabular}


Jurnal Akuntansi \& Perpajakan, Volume 1, No. 2, Januari 2020

\begin{tabular}{|c|c|c|}
\hline 4 & CEKA & $\begin{array}{l}\text { WILMAR CAHAYA } \\
\text { INDONESIA TBK }\end{array}$ \\
\hline 5 & CINT & $\begin{array}{c}\text { CHITOSE } \\
\text { INTERNASIONAL TBK }\end{array}$ \\
\hline 6 & DVLA & $\begin{array}{c}\text { DARYA-VARIA } \\
\text { LABORATORIA TBK }\end{array}$ \\
\hline 7 & INDF & $\begin{array}{l}\text { INDOFOOD SUKSES } \\
\text { MAKMUR TBK }\end{array}$ \\
\hline 8 & KINO & $\begin{array}{l}\text { KINO INDONESIA } \\
\text { TBK. }\end{array}$ \\
\hline 9 & LMPI & $\begin{array}{c}\text { LANGGENG } \\
\text { MAKMUR INDUSTRI } \\
\text { TBK }\end{array}$ \\
\hline 10 & MBTO & $\begin{array}{l}\text { MARTINA BERTO } \\
\text { TBK. }\end{array}$ \\
\hline 11 & MRAT & MUSTIKA RATU TBK \\
\hline 12 & PSDN & $\begin{array}{l}\text { PRASIDHA ANEKA } \\
\text { NIAGA TBK. }\end{array}$ \\
\hline 13 & PYFA & $\begin{array}{c}\text { PYRAMIDA FARMA } \\
\text { TBK }\end{array}$ \\
\hline 14 & SKBM & SEKAR BUMI TBK. \\
\hline 15 & SKLT & SEKAR LAUT TBK \\
\hline 16 & TSPC & $\begin{array}{c}\text { TEMPO SCAN } \\
\text { PACIFIC }\end{array}$ \\
\hline 17 & ULTJ & $\begin{array}{lr}\text { ULTRA } & \text { JAYA } \\
\text { INDUSTRY } & \text { MILK } \\
\text { TRADING COMPANY }\end{array}$ \\
\hline
\end{tabular}

\begin{tabular}{|l|l|lr|}
\hline 18 & WIIM & $\begin{array}{l}\text { WISMILAK INTI } \\
\text { MAKMUR TBK }\end{array}$ & \\
& & & \\
\hline
\end{tabular}

Sumber: data IDX dan diolah oleh penulis

Analisis Statistika Deskriptif

Tabel Analisis Deskriptif

\begin{tabular}{|l|l|l|l|}
\hline & $\begin{array}{l}\text { Nilai } \\
\text { Perusahaan }\end{array}$ & Profitabilitas & $\begin{array}{l}\text { Investasi } \\
\text { Aset tetap }\end{array}$ \\
\hline $\begin{array}{l}\text { Average } \\
\text { (Mean) }\end{array}$ & 0.4566105 & 0.043138 & 0.035634 \\
\hline $\begin{array}{l}\text { Maximum } \\
\text { (Rp.) }\end{array}$ & 1,504226 & 0,1674 & 0,265893 \\
\hline $\begin{array}{l}\text { Minimum } \\
\text { (Rp.) }\end{array}$ & $-0,510199$ & $-0,0971$ & $-47,28898$ \\
\hline $\begin{array}{l}\text { Standard } \\
\text { Deviasi }\end{array}$ & 0.48092 & 0.05033 & 0.06559 \\
\hline N & 54 & 54 & 54 \\
\hline
\end{tabular}

Sumber: data diolah dengan Microsoft Excel

Nilai maksimum pada variabel nilai perusahaan adalah sebesar 1.504226119 yang diperoleh perusahaan dengan kode saham KINO (2015), hal ini disebabkan karena pada tahun tersebut harga pasar perusahaan sangat tinggi karena pada saat IPO di 2015, KINO dianggap memiliki fundamental yang baik, sifatnya mass product, sehingga dianggap memiliki prospek yang baik juga . Variabel profitabilitas adalah sebesar 0.1674 yang diperoleh perusahaan dengan kode saham ULTJ (2016), hal ini disebabkan karena pada tahun tersebut pendapatan perusahaan meningkat sedangkan perusahaan tidak menambah aset tetap, 
Jurnal Akuntansi \& Perpajakan, Volume 1, No. 2, Januari 2020

juga pada tahun 2016 kurs Rupiah terhadap USD melemah sejak akhir 2015 yang menyebabkan konsumen beralih ke produk dalam negeri karena alasan harga produk yang lebih terjangkau bagi masyarakat. Variabel investasi aset tetap adalah sebesar 0.265892582 yang diperoleh perusahaan dengan kode saham SKLT (2016), hal ini disebabkan karena

pembelian aset tetap yang baru karena aset tetap yang lama sudah using, sehingga pada tahun tersebut perusahaan melakukan investasi yang cukup besar sehingga NFA akhir tahun lebih besar 2 kali lipat dibandingkan NFA awal tahun yang menjadikan persentase CAPBVA tinggi.

Nilai minimum pada variabel nilai perusahaan adalah sebesar -0.510199363 yang diperoleh perusahaan dengan kode saham CEKA (2017), hal ini disebabkan karena pada tahun yang bersangkutan perusahaan menambah debt dengan jumlah yang sangat besar dari pinjaman ke bank untuk kredit modal kerja dan kredit jangka pendek, juga revolving credit; selain itu perusahaan juga berfokus untuk menjual bahan baku industri seperti kernel (minyak inti kelapa sawit yang lebih jenuh). Nilai minimum variabel profitabilitas adalah sebesar -0.0971 yang diperoleh perusahaan dengan kode saham AISA (2017), hal ini disebabkan karena penurunan sales yang lebih besar daripada penurunan total aset tetap, selain itu karena produk dari AISA yang kurang inovatif dan kurang bersaing dari segi harga maupun kualitas produk. Nilai minimum variabel investasi aset tetap adalah sebesar 0.047288981 yang diperoleh perusahaan dengan kode saham PYFA (2015), hal ini disebabkan karena pada tahun 2014 perusahaan memiliki menambah aset tetap

sehingga penyusutan aset tetap di tahun 2015 menjadi semakin besar dan tidak ada penambahan aset tetap di tahun 2015

\section{Analisis Regresi Data Panel}

Sebelum melakukan pengujian peneliti perlu melihat normalitas dari variabel $\mathrm{Y}$ yaitu menggunakan uji Jarque-Bera.

\section{Tabel Hasil Uji Normal}

Uji Normalitas J

arque-Bera

NILAI_PERUSAHAAN_Y

Mean 0.456611

Median $\quad 0.519928$

Maximum 1.504226

Minimum $\quad-0.510199$

Std. Dev. $\quad 0.480921$

Skewness $\quad-0.159213$

Kurtosis $\quad 2.426004$

Jarque-Bera 0.969450

Probability 0.615867

Sum 24.65697

Sum Sq. Dev. 12.25809

Sumber : Hasil Uji Normal 2019

Hasil pada uji Jarque-Bera menunjukan tingkat probability $\mathbf{0 . 6 1 5 8 6 7}$ yang lebih besar dari tingkat $\alpha=0.05$ (tolak $\mathrm{H} 0$ dan terima $\mathrm{H} 1$ ) sehingga dapat disumpulkan bahwa data berdasarkan variabel $\mathrm{Y}$ pada data penelitian terdistribusi normal. Karena data terdistribusi normal, maka bisa dilanjutkan dengan uji statistik induktif dengan regresi.

Dari pengujian data panel menggunakan EVIEWS dengan Chow Test dan hausman Test 
Jurnal Akuntansi \& Perpajakan, Volume 1, No. 2, Januari 2020

didapat model terbaik untuk penelitian ini adalah

Fixed Effect Model (FEM).

Tabel 4.6. Fixed Effect Model Dependent Variabel:

NILAI_PERUSAHAAN__Y

Method: Panel Least Squares

Date: 06/29/19 Time: 19:38

Sample: 20152017

Periods included: 3

Cross-sections included: 18

Total panel (balanced) observations: 54

\begin{tabular}{|l|l|l|l|l|}
\hline $\begin{array}{l}\text { Variab } \\
\text { el }\end{array}$ & $\begin{array}{l}\text { Coef } \\
\text { f }\end{array}$ & $\begin{array}{l}\text { Std } \\
\text { error }\end{array}$ & t-stat & Prob \\
\hline C & $\begin{array}{l}0.342 \\
168\end{array}$ & $\begin{array}{l}0.061 \\
491\end{array}$ & 5.564515 & 0.0000 \\
\hline $\begin{array}{l}\text { PROFI } \\
\text { TABIL }\end{array}$ & $\begin{array}{l}2.270 \\
923\end{array}$ & $\begin{array}{l}1.093 \\
717\end{array}$ & 2.076334 & 0.0455 \\
ITAS_ & & & & \\
\hline IF__ & 0.462 & 0.636 & 0.726358 & 0.4726 \\
X2_- & 400 & 601 & & \\
\hline
\end{tabular}

\begin{tabular}{|c|c|c|c|}
\hline \multicolumn{4}{|c|}{ Effect Specification } \\
\hline \multicolumn{4}{|c|}{ Cross-section fixed (dummy variabels) } \\
\hline R-squared & $\begin{array}{l}0.880 \\
591\end{array}$ & $\begin{array}{l}\text { Mean } \\
\text { dependent } \\
\text { var }\end{array}$ & $\begin{array}{l}0.4566 \\
11\end{array}$ \\
\hline $\begin{array}{l}\text { Adjusted } \\
\text { R-squared }\end{array}$ & $\begin{array}{l}0.813 \\
863\end{array}$ & $\begin{array}{l}\text { S.D. } \\
\text { dependent } \\
\text { var }\end{array}$ & $\begin{array}{l}0.4809 \\
21\end{array}$ \\
\hline $\begin{array}{l}\text { S.E. of } \\
\text { regression }\end{array}$ & $\begin{array}{l}0.207 \\
487\end{array}$ & $\begin{array}{l}\text { Akaike } \\
\text { info } \\
\text { criterion }\end{array}$ & $\begin{array}{l}- \\
0.0293 \\
83\end{array}$ \\
\hline $\begin{array}{l}\text { Sum } \\
\text { squared } \\
\text { resid }\end{array}$ & $\begin{array}{l}1.463 \\
723\end{array}$ & $\begin{array}{l}\text { Schwarz } \\
\text { criterion }\end{array}$ & $\begin{array}{l}0.7072 \\
77\end{array}$ \\
\hline $\begin{array}{l}\log \\
\text { likelihood }\end{array}$ & $\begin{array}{l}20.79 \\
335\end{array}$ & $\begin{array}{l}\text { Hannan- } \\
\text { Quinn } \\
\text { criter }\end{array}$ & $\begin{array}{l}0.2547 \\
18\end{array}$ \\
\hline F-statistic & $\begin{array}{l}13.19 \\
665\end{array}$ & $\begin{array}{l}\text { Durbin- } \\
\text { Watson } \\
\text { stat }\end{array}$ & $\begin{array}{l}2.4970 \\
53\end{array}$ \\
\hline
\end{tabular}

\begin{tabular}{|l|l|l|l|}
\hline $\begin{array}{l}\text { Prob(F- } \\
\text { statistic) }\end{array}$ & & & \\
\hline
\end{tabular}

Sumber: data diolah dengan menggunakan Eviews

Pembahasan

Model regresi yang terbentuk dalam penggunaan fixed effect model yaitu:

\section{NILAI PERUSAHAAN $=\mathbf{0 . 3 4 2 1 6 8 +}$ \\ 2.270923PROFITABILITAS + 0.462400IFA}

Persamaan di atas menunjukan variabel profitabilitas dan investasi aset tetap (IFA) berpengaruh positif terhadap nilai perusahaan.

Profitabilitas diharapkan bisa menggambarkan prospek perusahaan di masa depan, sehingga nilai perusahaan dapat dilihat dari profitabilitas perusa haan sebagai sinyal positif. Berdasarkan estimasi dari tabel di atas dengan menggunakan metode Fixed Effect Model tingkat profitabilitas perusahaan memiliki probabilita sebesar $0.0455(<0.05)$ dan dianggap signifikan. Koefisien profitabilitas perusahaan terhadap nilai perusahaan sebesar 2.270923, menunjukan bahwa profitabilitas perusahaan mempengaruhi nilai perusahaan secara positif sebesar $\mathbf{2 . 2 7 0 9 2 3}$ per satuan nilai perusahaan. Dengan demikian dapat disimpulkan bahwa variabel profitabilitas memiliki pengaruh positif dan signifikan terhadap nilai perusahaan. Dalam penelitian ini, teori signaling terbukti bahwa profitabilitas yang tinggi memberikan sinyal positif bagi para investor sehingga harga saham (nilai perusahaan) naik. Dapat dilihat juga dari contoh perusahaan KINO di tahun 2015 yang memiliki profitabilitas 8,2\% 
Jurnal Akuntansi \& Perpajakan, Volume 1, No. 2, Januari 2020

menghasilkan nilai perusahaan (Tobin's Q) sebesar 150,42\%, sedangkan PYFA di tahun 2015 yang memiliki profitabilitas $1,93 \%$ menghasilkan nilai perusahaan (Tobin's Q) sebesar 27.65\%.

Dari hasil penelitian yang ada, variable profitabilitas memiliki pengaruh positif dan signifikan terhadap nilai perusahaan, sejalan dengan penelitian yang dilakukan oleh Dewi dan Wirajaya (2013), Pratama dan Wirawati (2013), Rasyid, Mahfudnurnajamuddin, Mas'sud dan Su'un (2015), dan Wijaya dan Sedana (2015). Dengan begitu, perusahaan yang mengalami peningkatan laba mencerminkan bahwa perusahaan mempunyai kinerja yang baik, sehingga memberikan signal positif kepada investor untuk berinvestasi (sesuai dengan teori signaling) dan dapat membuat harga saham perusahaan mengalami peningkatan, meningkatnya harga saham di pasar berarti meningkat pula nilai perusahaan di mata investor.

Selain itu, penelitian ini juga bertentangan dengan hasil penelitian yang dilakukan oleh Noviyanto (2008) yang menunjukkan bahwa profitabilitas tidak berpengaruh terhadap nilai perusahaan.

Investasi aset tetap juga diharapkan bisa memberikan sinyal positif bagi para investor (meningkatkan nilai perusahaan) sehingga menarik investor untuk berinvestasi di perusahaan tersebut. Investasi aset tetap menunjukan tingkat probabilita sebesar 0.4726 dan dianggap tidak signifikan karena lebih besar dari nilai signifikasi (0.05).
Koefisien dari investasi aset tetap (IFA) terhadap nilai perusahaan sebesar $\mathbf{0 . 4 6 2 4 0 0}$ menunjukan bahwa investasi aset tetap (IFA) mempengaruhi nilai perusahaan secara positif sebesar $\mathbf{0 . 4 6 2 4 0 0}$ per satuan nilai perusahaan. Berdasarkan teori dari Myers(1977) investasi aset tetap memberikan sinyal positif, dan faktanya dari penelitian ini dapat dilihat bahwa investasi aset tetap berpengaruh positif terhadap nilai perusahaan, namun pengaruhnya tidak signifikan. Sedikit berbeda dari hasil penelitian variable $\mathrm{X} 1$, variable $\mathrm{X} 2$ dalam penelitian ini yaitu investasi aset tetap juga memiliki pengaruh yang positif terhadap nilai perusahaan, namun tidak signifikan, sejalan dengan penelitian yang dilakukan oleh Murhadi W. R. (2008), investasi aset tetap memiliki pengaruh positif namun tidak signifikan terhadap nilai perusahaan. Hal ini menunjukkan bahwa perusahaan mampu mengelola tambahan modal saham perusahaan untuk meningkatkan aktiva produktif sehingga berpotensi dalam meningkatkan pertumbuhan perusahaan. Di sisi lain, hasil dari penelitian ini bertentangan dengan hasil penelitian yang dilakukan oleh Feixue Xie (2000), Susanny (2011) yang menyatakan bahwa investasi aset tetap tidak berpengaruh terhadap nilai perusahaan.

Karena 13 dari 18 perusahaan yang diteliti oleh penulis mempunyai proporsi aset lancar yang lebih besar daripada aset tetapnya sehingga pada hasil pengolahan data pengaruh investasi aset tetap terhadap nilai perusahaan tidak signifikan. 5 perusahaan yang mempunyai proporsi aset lancar 
Jurnal Akuntansi \& Perpajakan, Volume 1, No. 2, Januari 2020

yang lebih kecil daripada aset tetapnya adalah perusahaan dengan kode saham ADES, ALTO, INDF, PYFA, SKLT. 5 perusahaan tersebut memiliki penjualan yang sangat besar dan investor dan calon investor agar tidak melihat sekilas dalam berinvestasi, khususnya pada saat perusahaan berinvestasi di aset tetap. Karena belum tentu investasi tersebut dapat menaikkan nilai perusahaan.umumnya adalah market leader, sebagai contoh produknya ialah air mineral (ADES \& ALTO), mie instan (INDF), obat luka luar (PYFA), bumbu masak rumahan (SKLT). Dengan begitu kenaikan investasi aset tetap tidak berpengaruh terhadap nilai profitabilitas dan nilai perusahaan.

\section{CONCLUSION}

Berdasarkan hasil pengolahan data dan analisis pada bab sebelumnya terhadap 18 perusahaan manufaktur subsektor konsumsi yang terdaftar di Bursa Efek Indonesia pada periode 2015-2017 dengan menggunakan regresi data panel dimana fixed effect model dipilih sebagai model yang paling cocok untuk penelitian ini, menghasilkan kesimpulan bahwa Variabel independen profitabilitas yang diproksikan dengan Return of Assets (ROA) memiliki pengaruh positif dan signifikan terhadap variabel dependen (nilai perusahaan). Diremukan juga bahwa Variabel independen investasi aset tetap yang diproksikan dengan Capital Expenditure to Book Value Assets (CAPBVA) memiliki pengaruh positif, namun tidak signifikan terhadap variabel dependen (nilai perusahaan). Dan dengan melihat hasil penelitian ini diharapkan investor dan calon investor agar tidak melihat sekilas dalam berinvestasi, khususnya pada saat perusahaan berinvestasi di aset tetap. Karena belum tentu investasi tersebut dapat menaikkan nilai perusahaan. Peneliti selanjutnya dapat menambah jumlah sampel penelitian, dengan memperluas ruang lingkup dari industri yang ada, tentunya yang berhubungan dengan variabel-variabel yang ada. Menentukan subjek penelitian terlebih dahulu, dan dilanjutkan dengan pemilihan proksi penelitian. Jika menggunakan proksi CAPBVA maka sebaiknya diawali dengan mengambil sampel yang seimbang antara perusahaan yang didominasi aset lancar dan perusahaan yang didominasi aset tetap, agar bisa lebih menjelaskan fenomena yang ada dengan lebih akurat dan lebih signifikan.

\section{REFERENCES}

Agus, R. Sartono. (2010). Manajemen Keuangan Teori dan Aplikasi. Edisi Keempat. Yogyakarta: BPFE.

Bodie, Z., Kane,A., \& Marcus A.J. (2014). Manajemen Portfolio dan Investasi (Edisi 9). Jakarta: Salemba Empat.

Brigham, E. F., \& Houston, J. F. (2009). Fundamentals of Financial Management: Concise, Twelfth Edition. Boston: Cengage Learning

Chung, K. H., \& Pruitt, S. W. (1994). A Simple Approximation of Tobin's Q. Financial Management Journal, Vol 23(Iss 3), 70-74

Dewi, A. S. M., Wirajaya, A., (2013). Pengaruh Struktur Modal, Profitabilitas dan Ukuran Perusahaan pada Nilai Perusahaan. E-Jurnal Akuntansi Universitas Udayana 4.2 
Jurnal Akuntansi \& Perpajakan, Volume 1, No. 2, Januari 2020

Fernandar, G.I. (2012). Pengaruh Keputusan Investasi, Keputusan Pendanaan, dan Kebijakan Dividen terhadap Nilai Perusahaan. Universitas Diponegoro Semarang

Gagaring, Palagung. 2003. "Pengaruh Kombinasi Keunggulan dan Keterbatasan Perusahaan terhadap Set Kesempatan Investasi (IOS)". Jurnal Riset Akuntansi Indonesia. Volume-6 Ikatan Akuntan Pendidik.

Gaver, J.J., \& Gaver, K.M. (1993). "Additional Evidenve on the Association Between Investment Opportunity Set and Corporate Financing Dividend, and Compensation Policies". Journal of Accounting and Economic, 125-160.

Hardiyanti, N. (2012). Analisis Pengaruh Insider Ownership, Leverage, Profitabilitas, Firm Size, dan Dividen Payout Ratio terhadap Nilai Perusahaan. Skripsi. Universitas Diponegoro. Semarang.

Hidayah, N., (2015). Pengaruh Investment Opportunity Set Dan Kepemilikan Manajerial Terhadap Nilai Perusahaan Pada Perusahaan Property Dan Real Estate Di Bursa Efek Indonesia. Jurnal Akuntansi / Vol.XIX, No.03

Kasmir. (2008). Bank dan Lembaga Keuangan lainnya (edisi revisi). Jakarta: PT. Rajagrafindo

Maulidah, R. (2012). Akuntansi Pemerintahan. Jakarta: Salemba Empat

May, A. (2017). Simple Descriptive Statistics. Dalam The SAGE Encyclopedia of Communication Research Methods (hal. 1602-1606). Thousand Oaks: SAGE Publications, Inc.

Myers, Stewart C. (1977). "Determinant of Corporate Borrowing", Journal of Financial Economics 5. Pp. 147-175, 1984 The Capital Structure Puzzle

Noviyanto, Dwi. (2008). Pengaruh Rasio Profitabilitas dan Rasio Investor terhadap Nilai Perusahaan pada Perusahaan LQ45 di Bursa Efek Jakarta tahun 20052007. Skripsi. Universitas Negeri Malang

Pratama, I G. G. W., Wirawati, Ni G. P., (2016). Pengaruh Struktur Modal Dan Profitabilitas Terhadap Nilai Perusahaan Dengan Kepemilikan Manajerial
Sebagai Pemoderasi. E-Jurnal Akuntansi Universitas Udayana, Vol.15.3

Rasyid A., Mahfudnurnajamuddin, Mas'sud M., Muhammad Su'un. (2015). Effect of Ownership Structure, Company Size and Profitability on Dividend Policy and Manufacturing Company's Value in Indonesia Stock Exchange. Australian Journal of Basic and Applied Sciences. 9(20): pp: 618-624

Ratnawati, T. 2007. Pengaruh langsung dan tidak langsung faktor ekstern, kesempatan investasi dan pertumbuhan aset terhadap keputusan pendanaan perusahaan yang terdaftar pada Bursa Efek Jakarta: Studi pada Industri Manufaktur Masa Sebelum Krisis dan Saat Krisis. Jurnal Akuntansi dan Keuangan 9: 6575

Ross, S. A., Westerfield, R. W., \& Jordan, B. D. (2010). Fundamentals of Corporate Finance. New York: McGraw-Hill/Irwin

Saphiro,A.C. (2014). Multinational Financial Management. United States Of America: John Wiley \& Sons

Sartono, A. (2010). Manajemen Keuangan dan Teori Aplikasi $\left(4^{\text {th }}\right.$ ed). Yogyakarta: BPFE

Sembel, R., Sugiharto, T. (2009). The Art of BEST WIN. Jakarta: PT Elex Media Komputindo Kompas Gramedia

Shleifer, A., \& Vishny, R.W. (1989). Management Entrenchment: The Case of Manager-Specific Investments. Journal of Financial Economics, 25, 123139

Soejono, Fransiska. (2010). Pengaruh Kepemilikan, Keputusan Investasi, Pengalaman dan Kinerja Finansial. Jurnal Bisnis dan Akuntansi, 12(1), 29-38

Surya, D., \& Rahayuningsih, D.A. (2012). FaktorFaktor yang Mempengaruhi Kebijakan Hutang Perusahaan Non Keuangan yang Terdaftar dalam Bursa Efek Indonesia. Jurnal Bisnis dan Akuntansi. Vol. 14, No.3, 213-225

Wahyuni,T., Ernawati, E., Murhadi, W.R. (2013). Faktor-Faktor Yang Mempengaruhi Nilai Perusahaan Di Sektor Property, Real Estate \& Building Construction Yang Terdaftar Di Bei Periode 2008- 
Jurnal Akuntansi \& Perpajakan, Volume 1, No. 2, Januari 2020

2012. Calyptra: Jurnal Ilmiah Mahasiswa Universitas

Surabaya; Vol.2; No.1 